\title{
An Investigation of Factors Affecting the Employees' Quality of Work Life and Assessment of the Status of These Factors
}

\author{
Hamed Mohammadi ${ }^{1}$, Mahsa Tavakoli ${ }^{2}$, Sahar Yazdanian $^{3}$, Mohammad Babaei ${ }^{4}$ \\ ${ }^{1}$ Ph.D. in Public Administration, Human Resource Expert at Mazandaran Gas Company, Iran \\ ${ }^{2} \mathrm{MSc}$ at Department of Educational Management, Faculty of Human Science, Islamic Azad University Sari Branch, \\ Iran \\ ${ }^{3} \mathrm{MSc}$ at Department of Accounting, Faculty of Human Science, Islamic Azad University, Sari Branch, Iran \\ ${ }^{4} \mathrm{PhD}$ Candidate in Public Administration, Islamic Azad University, Ghaemshahr Branch, Iran \\ Correspondence: Hamed Mohammadi, Ph.D. in Public Administration, Human Resource Expert at Mazandaran Gas \\ Company, Iran.
}

Received: June 20, 2017

doi:10.11114/bms.v3i4.2779
Accepted: November 6, 2017

Online Published: November 7, 2017

URL: https://doi.org/10.11114/bms.v3i4.2779

\begin{abstract}
The present study investigated the factors affecting the quality of work life of employees and assessed the status of these components in Mazandaran Gas Company. The population of this study included the employees of this company, and statistical sample involved 329 employees. Walton model was used to study the quality of work life components. To analyze data, test research hypotheses, and assess the status of components, the Chi-square test, Wilcoxon, Friedman, and confirmatory factor analysis were used. The results revealed that fair and appropriate compensation, providing opportunities for continued growth and safety, social relevance of work life, and development of human capacities were at a good status, and healthy and safe environment as well as social cohesion and integration were at an average status, and total space of life and constitutionalism were at an adverse status.
\end{abstract}

Keywords: quality of work life, adequate and fair compensation, providing opportunities for continued growth and safety, social relevance of work life, development of human capacities

\section{Introduction}

The efficient human capital is the most important capital within organizations (Troshani etal, 2011, p.470; Roos \& Roos, 1997, p.418), and the higher and more optimal the quality, the greater the possibility of organization's success, survival, and promotion would be. Therefore, great attempt must be made to improve human resources qualitatively since this will be of benefit to both organizations and employees. Optimal use of human resources relies on measures taken to preserve and protect the body and soul of organization's employees. These measures include leisure amenities and health services, incentive plans, job safety, the importance of the role and position of the individuals within organization, providing the grounds for employees' growth and development, and so on which are called "the quality of working life (QWL)" (Filipo,1988, p.412).

In recent decades, the increasing impact of factors such as globalization, information technology, corporate competition, and limited natural resources have changed individuals' perspectives regarding the definition of a successful company. In the past, financial resources were the most crucial factors in the definition of a successful company. Financial benefits that employees receive are very important to drive his or her QWL level (Sinha, 2012, pp.31-40).

Explaining balanced scorecard model, Kaplan and Norton (1996, p.78) emphasized the financial aspects as well as the development and learning, customer, and internal processes to measure the overall performance of the organizations. Balanced scorecard is a method using which both financial measures and nonfinancial measures -staff training, participation, expertise, and quality of information systems etc.- are evaluated.

Since the mid-1980s, approaches to human resources have changed from organizational factors to human resource factors (Maxwell, 2005, pp.189-179).

In recent years, ethics, QWL, and job satisfaction were increasingly considered the essential factors for the success and 
stability of the organizations. Along with the importance of ethics, QWL and job outcomes such as job satisfaction and organizational commitment are deemed the important issues in human resources and organizational development. Most writers and researchers in human resources management and organizational development associate the QWL and job outcomes with ethics, efficiency, social responsibility of corporate and organizational performance(Koonme \& Singhapakdi, 2009).

One of the most important issues in any organization is the quality of working life, which is the best index/indicator to attract and retain employees, leads to job satisfaction, and has in turn a significant effect (Mohammad Noor \& Abdullah, 2011, pp.745-739).

In some organizations, quality of working life programs intend to increase the employees' trust, involvement/engagement, and problem solving ability, and consequently increase satisfaction and effectiveness of the organization (Akder, 2006, p.173)

Maintenance of organizations' employees- specially managers' maintenance is more broader than associating individuals with the rights and received benefits or providing health or safety in the workplace. By the way, it should not be assumed that employees' expectations of their organizations are similar anywhere and in any working place, and that these expectations are easily recognized. Any cultural environment image of QWL is a special image of which managers should try to understand, organizations should pay attention to QWL for four reasons:

- As a culture, QWL creates a high level of mutual commitment between individuals and organization; that is, individuals should be committed to the organization's goals and development, and organizations should also be committed to individuals' needs and growth.

- As a goal, QWL improves organizational performance through creating jobs and more challenging, satisfying, and effective working environments for individuals at all organizational levels.

- As a process, QWL provides the opportunities to achieve the goals through involvement and participation of all people within organization.

- QWL is a phenomenon transcending organization borders, the effects of which can be found in the personal life of individuals and outside the organization.

Therefore, the purpose of this study was to examine and assess factors affecting employees' QWL in Mazandaran gas company, Iran, based on Walton model.

As a key factor in economic and social development, Gas Company plays a vital role in increasing the citizens' social welfare and the development of industrial infrastructure through the continuous provision of clean and safe energy supplies. Lack of attention to the employees' quality of working life in Gas Company can seriously hinder the provision of safe gas energy to citizens and consumers, as well as affecting their private lives outside the workplace. At the same time, the high quality of working life positively influences both work and non-work lives. So, a field study was conducted in the company under investigation in order to evaluate the factors affecting the quality of employees' working life, using which the company's managers be able to apply more effective approaches and policies to improve the level of the factors which influence the quality of working life, which ultimately leads to employees' job satisfaction and improvement of company's performance.

\section{Literature of Review}

The purpose of Quality of Work Life management is to create an atmosphere of freedom, participation and autonomy in which the worker is a partner in sharing a common objective and subjective indicators (Susan \& Jayan, 2013, p.91).

Measuring and assessment of the quality of working life began in the late 1960s, which was related to individual aspects of working, and focused on the relationship between the worker and the working environment.

The Companies have applied quality of life at work (QWL) as a strategy to improve performance, workers' productivity and competitively, the quality of life at work, simultaneously reducing absenteeism, employee turnover, without raising the cost of management and providing a healthy environment, as well as increasing the affective commitment and the insertion of the worker in the company, pride and the satisfaction of workers (Zhao et al. 2013, Quick et al. 2013).

Quality of Work Life can be defined with regard to the employees' satisfaction, work related behaviours (Bagtasos, 2011, pp.1-8), Reward, Job Security, Social activities, Balance of work and Family(Kanten \& Sadulhah, 2012, pp.360-361).

In order to give organizations a wider view of the factors that influence the working experience, the concept of "work-related quality of life" was created. It involves factors such as working conditions, but also broader non-work factors that affect the employees' relationship with work, including general life satisfaction and work-home interface (Alfonso et al, 2016, p.110). 
Robbins (1989) defined QWL as "a process by which an organization responds to employee needs by developing mechanisms to allow them to share fully in making the decisions that design their lives at work".

Quality of work life has different meanings to different people. Terms like "Work improvement", "Job enrichment", "Worker's participation", "Industrial democracy" have been widely used to mean quality of working life programme implemented (Teryima etal, 2016, p.269).

According to Lau and Bruce (1998), QWL is a dynamic multidimensional construct that currently includes such concepts as job security, reward systems, training and career advancements opportunities, and participation in decision making.

Wyatt and Wah (2001) believe that QWL demands a working environment in which employees' activities are considered valuable. It means that by adopting policies and strategies, work is planned in a way that leads to reduced monotony and increased variety and agility for employee.

A workplace contains quality in which individuals are considered as the main member and element of organization, individuals' mind is confronted with intellectual challenge, environmental condition develops and nurtures their capability, and everything can be done well in those environments (Belcher, 1987).

Almarsh (2015) listed the most important benefits of the employees' quality of working life as following:

- The degree to which superiors treat employees with respect.

- Diversity in the daily work schedule.

- Work challenge.

- The felling that proven work opens future opportunities for advancement.

- Self respect.

- Degree to which the life outside of work affects the life at work and the degree to which completed work contributes to society.

Stone (1998) states QWL components under the title of QWL criteria. He enumerates the major criterion for QWL as follow:

- Fair and adequate compensation: To what extent payments and interests are done to contribute to the maintenance of staff with an acceptable life standard?

- Safe and healthy environment: Is the physical condition of work dangerous? Which conditions affect the mental and physical health of employees?

- Development of human capacities: to what extent a job enables employees to apply and develop their skills, knowledge, and abilities, and to what extent the duties are satisfactory?

- Growth and safety: is there a potential career in job leading to growth and safety?

- Social cohesion: is there an opportunity to communicate with other people? Is progress based on merit? Is there equal chances?

- Respecting the fundamental rights of employees: is there any respect for employees' rights? Can employees express their thoughts and ideas freely? Are they treated like an adult? What are employees' rights and how they are protected?

- Total life space: is there any balance between work and life? Is there a high level of job stress?

- Social relations: do employees view the organization as a social responsibility? Does organization rates social values highly, especially when the policies are formulated and implemented, and measures are taken in line with employees, costumers, competitors, and society?

Tuttle (1983) states QWL in four characteristics as follows:

- Safety and safety, which includes job, mental, and physical safety

- Equitability and fairness of wages and compensations

- Providing grounds for growth and development of skills as well as continued learning

- Democracy and involvement in decision-making.

In order to measure the quality of working life in private and public banks, Reddy and Reddy (2014) considered the following 9 dimensions: Like, Emoluments, Safe and Healthy working conditions, Social integration, Social relevance of work, Constitutionalism, Opportunities to develop human capabilities, Career planning, Growth development, Work with job enrichment, and organization structure .

Moreover, the QWL was inversely related primarily to the lack of recognition, the lack of time, the poor consideration for patients and their families, the lack of training and the lack of collaboration, and also positively related to job characteristics, organizational climate, organizational commitment and job satisfaction (Giang \& Tung, 2016, p.195). 
Table 1. Results of research on QWL components

\begin{tabular}{|c|c|}
\hline Researchers & QWL indicators \\
\hline Stein(1983) & $\begin{array}{l}\text { 1. Independence and autonomy, 2. Identification and importance, } 3 \text {. Property and belongings, } \\
\text { 4. Growth and development, 5. Outside incentives }\end{array}$ \\
\hline $\begin{array}{l}\text { Levine \& Taylor \& } \\
\text { Davis(1984) }\end{array}$ & $\begin{array}{l}\text { 1. Respected by supervisor and trusting employees' capabilities, } 2 \text {. Change of work, } 3 \text {. Work } \\
\text { challenges, } 4 \text {. The opp0rtinuity for growth in the future resulting from the existing work, } 5 \text {. } \\
\text { Self-esteem, } 6 \text {. The degree of cohesion and interference between work and life, } 7 \text {. } \\
\text { Contribution of work in society promoting. }\end{array}$ \\
\hline $\begin{array}{l}\text { Rethinam \& } \\
\text { Maimunah (2008) }\end{array}$ & $\begin{array}{l}\text { 1. Health and well-being, 2. Job security, 3. Job satisfaction, 4. Competence development, } 5 \text {. } \\
\text { The balance between work non work life }\end{array}$ \\
\hline $\begin{array}{l}\text { Martel \& } \\
\text { Dupuis(2006) }\end{array}$ & $\begin{array}{l}\text { 1.life quality: compensation of services, welfare, work security, work support, 2. Social } \\
\text { quality: rapport with the superior, coworkers, and customers, 3. Growth quality: collaborative } \\
\text { management, individual growth improvement, self-esteem, and work characteristics }\end{array}$ \\
\hline Mitchell(2012) & 1.Communication, 2.Supervision, 3.learning, 4.Involvement \\
\hline $\begin{array}{l}\text { Che Rose \& Beh \& } \\
\text { Uli \& Idris(2006) }\end{array}$ & $\begin{array}{l}\text { 1. Task, 2. Physical work environment, 3. Social environment within the organization, } 4 . \\
\text { Administrative system, 5. relationship between life on and off the job }\end{array}$ \\
\hline Jia Haiwei(2005) & 1. Need for survival, 2. Need for passion, 3. Need for belongings, 4. Need oneself \\
\hline $\begin{array}{l}\text { Almalki \& Fitzgerald } \\
\text { \& Clark (2012) }\end{array}$ & 1.Work life/home life, 2.work design, 3.work context, 4.work world \\
\hline $\begin{array}{l}\text { Lee \& } \\
\text { Singhapakdi(2007) }\end{array}$ & $\begin{array}{l}\text { 1. Workplace, } 2 \text {. Wages and benefits, } 3 \text {. Welfare, } 4 \text {. Promotion, } 5 \text {. Nature of work, } 6 . \\
\text { Education and development, } 7 \text {. Superior leadership style, } 8 \text {. Collaboration among coworkers, } \\
\text { 9. Organization mien, } 10 \text {. Communications, } 11 \text {. Organizational regulations, } 12 \text {. Organizational } \\
\text { climate and culture, } 13 \text {. Working time and working pressure }\end{array}$ \\
\hline Stephen (2012) & $\begin{array}{l}\text { 1. Adequate and fair compensation, 2. Fringe benefits and welfare measures, 3. Job security, } 4 \text {. } \\
\text { Physical work environment, 5. Work load and job stress, } 6 \text {. Opportunity to use and develop } \\
\text { human capacity, } 7 \text {. Opportunity for continued growth, } 8 \text {. Human relations and social aspect of } \\
\text { work life, } 9 \text {. Participation in decision making, 10. Reward and penalty system, 11. Equity, } \\
\text { justice and grievance handling, 12. Work and total life space, 13. Image of organization }\end{array}$ \\
\hline
\end{tabular}

\section{Research Methods}

Regarding the nature and goal, the present study is applied, and given the data-gathering method, it is a survey of descriptive (non-experimental) type.

And the most important advantage of surveys is generalizability of their findings. In other words, the method of this study is quantitative in that the dimensions of Walton's (1973) quality of life model will be tested in the studied company

To gather the data, two methods were used as follows:

1. Library method: To collect the data for laying the basic foundation of this research such as definition of key concepts, proposing requirements, expressing the application, and explaining its importance, library studies including studying articles, Persian and Latin books about QWL, similar thesis dissertations in this field, internet resources, and seminars were used.

2. Survey method: In order to collect the data for analysis, the questionnaire was used. QWL questionnaire consists of 29 items examining QWL based on Walton model.

To measure the items of the questionnaire, Likert scale has been used which is one of the most useful scales, especially in behavioral science research.

Table - the scales to measure the items

\begin{tabular}{c|c|c|c|c}
\hline Very much & much & average & low & Very low \\
\hline 5 & 4 & 3 & 2 & 1 \\
\hline
\end{tabular}

The statistical population of this study includes 459 formal employees of Gas company, And the form of probability sampling used in the study was stratified sampling.

and the size of required sample is determined based on Cohen, Morgan, and Krejcy table, and the sample size was calculated to be $210(n=210)$. 
Table 2. Statistical size of society and statistical sample size

\begin{tabular}{c|c|c}
\hline department & Employees' No & Sample No \\
\hline operation & 242 & 211 \\
\hline $\begin{array}{c}\text { Financial and } \\
\text { administrative }\end{array}$ & 80 & 37 \\
\hline engineering & 75 & 34 \\
\hline Staff units & 62 & 28 \\
\hline
\end{tabular}

The validity of questionnaire items was determined through different interviews and opinions of professors and experts in the field of human resources of company, and thereby, it was made certain that the questionnaire tests the same attribute as intended by the researcher. To measure the reliability of questionnaire, Cronbach's alpha was utilized. Therefore, first, a preliminary sample involving 30 questionnaires were pretested, then, using the data derived from the questionnaire, and applying SPSS statistical software, the reliability coefficient was measured through Cronbach's alpha.

Table 3. Reliability of items in terms of each component

\begin{tabular}{cc}
\hline component & alpha level \\
\hline Fair and adequate compensation & 0.81 \\
Healthy and safe environment & 0.85 \\
Providing opportunities for continued growth and safety & 0.82 \\
constitutionalism & 0.86 \\
Social relevance of work life & 0.83 \\
Total space of life & 0.82 \\
Social cohesion and integration & 0.85 \\
Development of human capacities & 0.81 \\
Total score of employees'QWL & 0.83 \\
\hline
\end{tabular}

The function of exploratory studies is to broaden the analytical perspectives and make the researcher familiar with the experts and theoreticians' thoughts whose research and thoughts may inspire the researchers in their research, and disclose different aspects of research problem. Analytical model is like a hinge linking the theoretical plan of research problem with its subsequent work which is observation and analysis of information. The conceptual statement of research topic phenomena is called conceptualization which is one of the main aspects of analytical model structure without which constructing an analytical model will not have a strong, solid, and accurate foundation.

\section{Research Methods}

The theoretical framework is a basis on which the whole research is established. This framework is a logical, descriptive, and cultured network involving the relationships among variables seeking to conduct such processes as interview, observation, and review of literature. These variables are inevitably associated with research problems. The theoretical framework of this study is based on the eight constituent components of Walton (1975) model based on which the impact of these eight variables on QWL of employees in Mazandaran Gas Company is investigated.

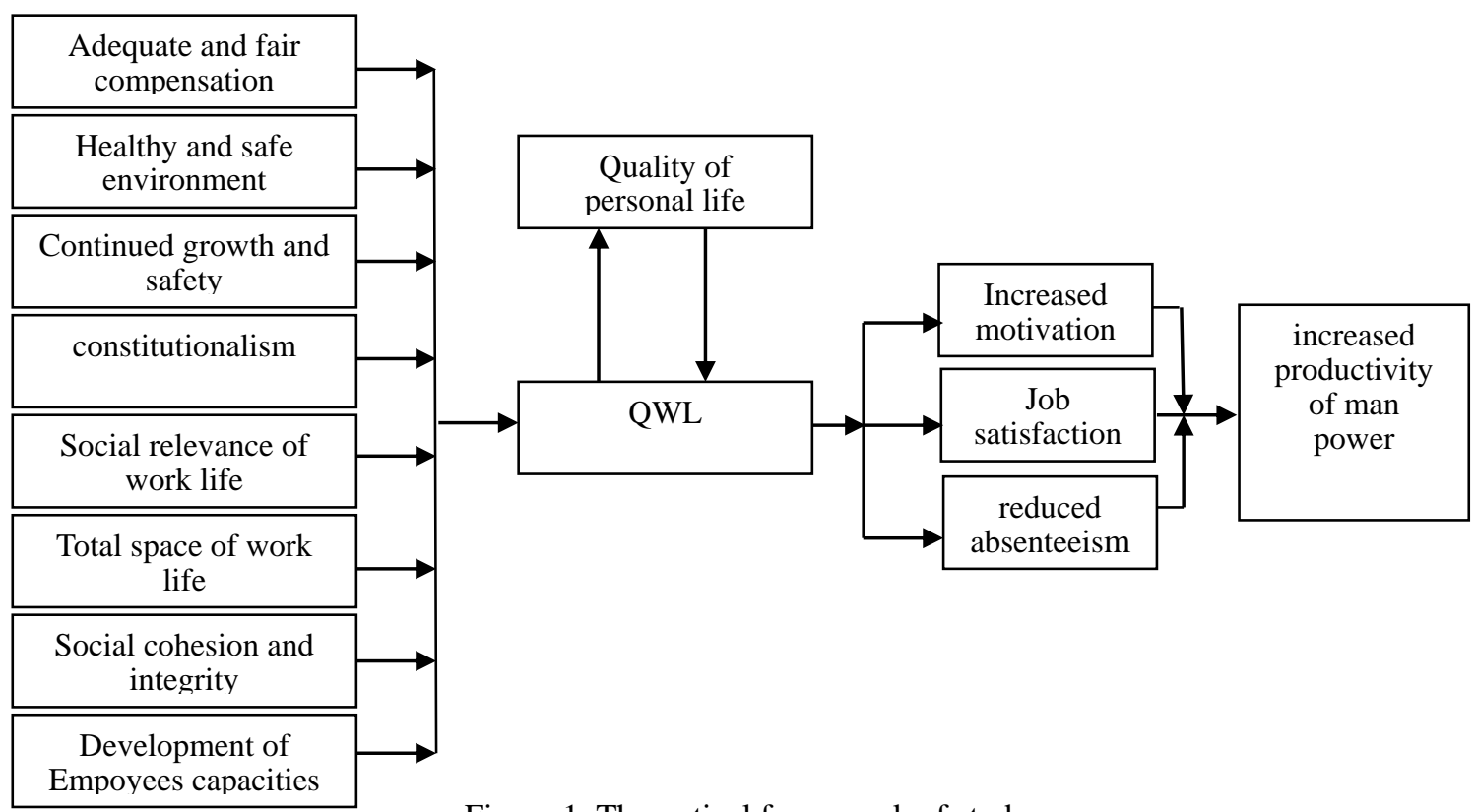

Figure.1. Theoretical framework of study 
Table 4. Analytical model of study

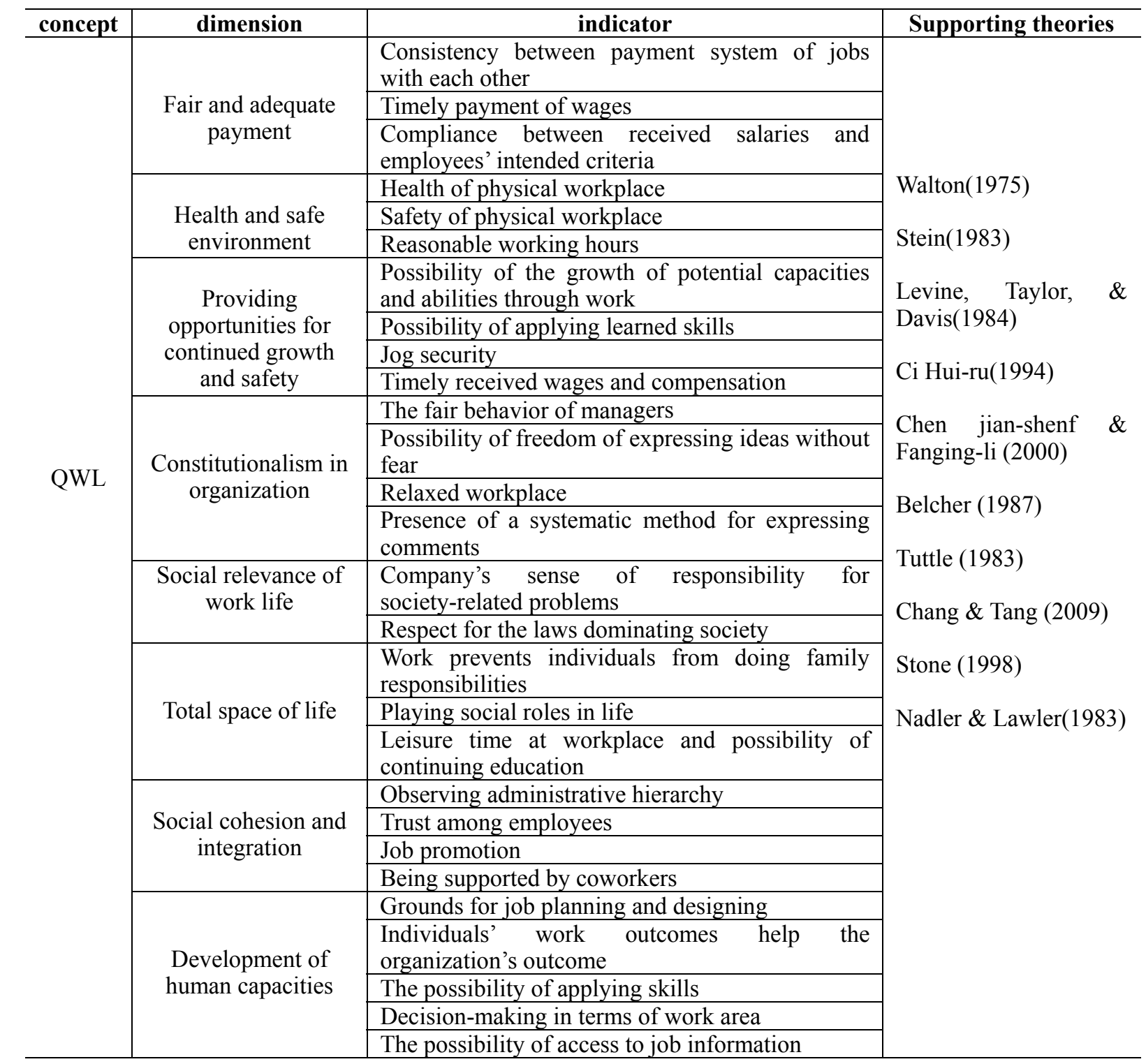

\section{Analysis}

In order to specify the type of test utilized for research hypotheses, first, we examined the normality and non-normality of data related to the hypotheses through Kolmogorov-Smirnov test, then non-parametric statistical methods were used by using the results of the study. Chi-square test was applied to examine the degree of individuals' answer to each component's questions.

Null hypothesis: Individuals do not agree with each other in answering questionnaire items.

Alternative hypothesis: Individuals agree with each other in answering questionnaire items. 
Table 5. Examining the degree of respondents' answer to each component questions

\begin{tabular}{c|c|c|c|c}
\hline P-Value & $\begin{array}{c}\text { critical } \\
\text { chi-square }\end{array}$ & DF & $\begin{array}{c}\text { Computational } \\
\text { chi-square }\end{array}$ & component \\
\hline 0.000 & 9.487 & 4 & 172.049 & Fair and adequate compensation \\
\hline 0.000 & 9.487 & 4 & 353.099 & Healthy and safe environment \\
\hline 0.000 & 9.487 & 4 & 356.352 & $\begin{array}{c}\text { Providing opportunities for } \\
\text { continued growth and safety }\end{array}$ \\
\hline 0.000 & 9.487 & 4 & 264.628 & Constitutionalism in organization \\
\hline 0.000 & 9.487 & 4 & 154.215 & Social relevance of work life \\
\hline 0.000 & 9.487 & 4 & 223.121 & Total space of life \\
\hline 0.000 & 9.487 & 4 & 371.523 & Social cohesion and integration \\
\hline 0.000 & 9.487 & 4 & 516.055 & Development of human capacities \\
\hline $\mathbf{0 . 0 0 0}$ & $\mathbf{9 . 4 8 7}$ & $\mathbf{4}$ & $\mathbf{2 0 7 5 . 5 4 3}$ & Total score \\
\hline
\end{tabular}

If individuals do not agree with each other in answering this question, they equally choose "very low", "low", "average", "high", and "very high" answers. Conversely, if they agree, most respondents will agree on choosing a certain option. In the above table, the Chi-square calculated in all tests is higher than critical Chi-square (9.487) with 4 degree of freedom and 0.05 significant level. On the other hand, the probability level (P-Value) is less than significance level (0.05). Therefore, it can be stated that at 0.05 significant level with $95 \%$ confidence, individuals agree with each other in answering each component questions. In what follows, it will be investigated whether, in spite of consensus on a special item, the median of answer in each component is higher than 3 or not?

Accordingly, Wilcoxon test will be applied to examine the status of each component.

Null hypothesis: The median of individuals' answer in each component equals to 3 .

Alternative hypothesis: The median of individuals' answer in each component is greater than 3 .

Table 6. Studying the median of answer in each component

\begin{tabular}{c|c|c|c|c|c}
\hline component & No & Wilcoxon-statistics & Median value & P-value & status \\
\hline $\begin{array}{c}\text { Fair and adequate } \\
\text { compensation }\end{array}$ & 219 & 9591.5 & 3.165 & 0.001 & appropriate \\
\hline Healthy and safe environment & 219 & 8043.5 & 3.000 & 0.178 & average \\
\hline $\begin{array}{c}\text { Providing opportunities for } \\
\text { continued growth and safety }\end{array}$ & 219 & 10077.5 & 3.125 & 0.005 & appropriate \\
\hline $\begin{array}{c}\text { Constitutionalism in } \\
\text { organization }\end{array}$ & 219 & 5539.0 & 2.275 & 1.000 & inappropriate \\
\hline Social relevance of work life & 219 & 10339.5 & 3.250 & 0.000 & appropriate \\
\hline Total space of life & 219 & 2192.0 & 2.500 & 1.000 & inappropriate \\
\hline $\begin{array}{c}\text { Social cohesion and } \\
\text { integration }\end{array}$ & 219 & 7331.5 & 3.000 & 0.878 & average \\
\hline $\begin{array}{c}\text { Development of human } \\
\text { capacities }\end{array}$ & 219 & 13073.0 & 3.200 & 0.000 & appropriate \\
\hline Total score & $\mathbf{2 1 9}$ & $\mathbf{1 1 7 6 6 . 0}$ & $\mathbf{2 . 9 9 0}$ & $\mathbf{0 . 6 1 7}$ & \\
\hline
\end{tabular}

According to results of Table 6, it can be observed that in safe and adequate compensation, providing opportunity for continued growth and safety, social relevance of work life, and development of human capacities, median is higher than 3 , and test is significant. However, in the health and secure environment as well as social cohesion and integrity, the median exactly equals to 3 , which shows an average amount. Furthermore, in constitutionalism in organization and total space of life, the median is less than 3 suggesting that more attention is needed to be paid to meeting the needs in these fields. Totally, the overall obtained score is relatively average, and the hypothesis for its higher amount is not confirmed.

Friedman test was used to compare the status of QWL components, and the degree of the status of intended components is compared with each other in employees' QWL.

Null hypothesis: The status of components is not the same.

Table 7. Comparing the status of QWL components

\begin{tabular}{c|c|c|c|c}
\hline No & $\begin{array}{c}\text { Computational } \\
\text { Chi-square }\end{array}$ & $\begin{array}{c}\text { Degree of } \\
\text { freedom }\end{array}$ & $\begin{array}{c}\text { Critical } \\
\text { chi-square }\end{array}$ & $\begin{array}{c}\text { Probability } \\
\text { level }\end{array}$ \\
\hline 219 & 231.174 & 7 & 14.067 & 0.000 \\
\hline
\end{tabular}


With respect to Table 7 , the values of computational chi-square statistics was about 231.174 higher than critical chi-square equaling 14.067 with 7 degrees of freedom and 0.05 significant level, and the values of corresponding likelihood was also less than significant level $(\alpha=0.05)$. The null hypothesis was, therefore, rejected, and it can be stated that the status of employees' QWL components is not similar. In other words, there is prioritization in assessing the status of components.

Table 8. Prioritizing the employees' QWL components in terms of mean of rank

\begin{tabular}{c|c|c}
\hline Priority & Components & Mean of ranks \\
\hline 1 & Social relevance of work life & 5.47 \\
\hline 2 & Development of human capacities & 5.24 \\
\hline 3 & Fair and adequate compensation & 5.00 \\
\hline 4 & Providing opportunities for continued growth and safety & 5.00 \\
\hline 5 & Healthy and safe environment & 4.74 \\
\hline 6 & Social cohesion and integration & 4.31 \\
\hline 7 & Constitutionalism in organization & 3.42 \\
\hline 8 & Total space of life & 2.80 \\
\hline
\end{tabular}

Radar diagram with a polygon has helped the researcher to detect the dominant variable (s) for a series of observations. In studying the diagram, 'social relevance of work life' is in the highest place with 'the total space of life' and 'constitutionalism' in the lowest place, respectively.

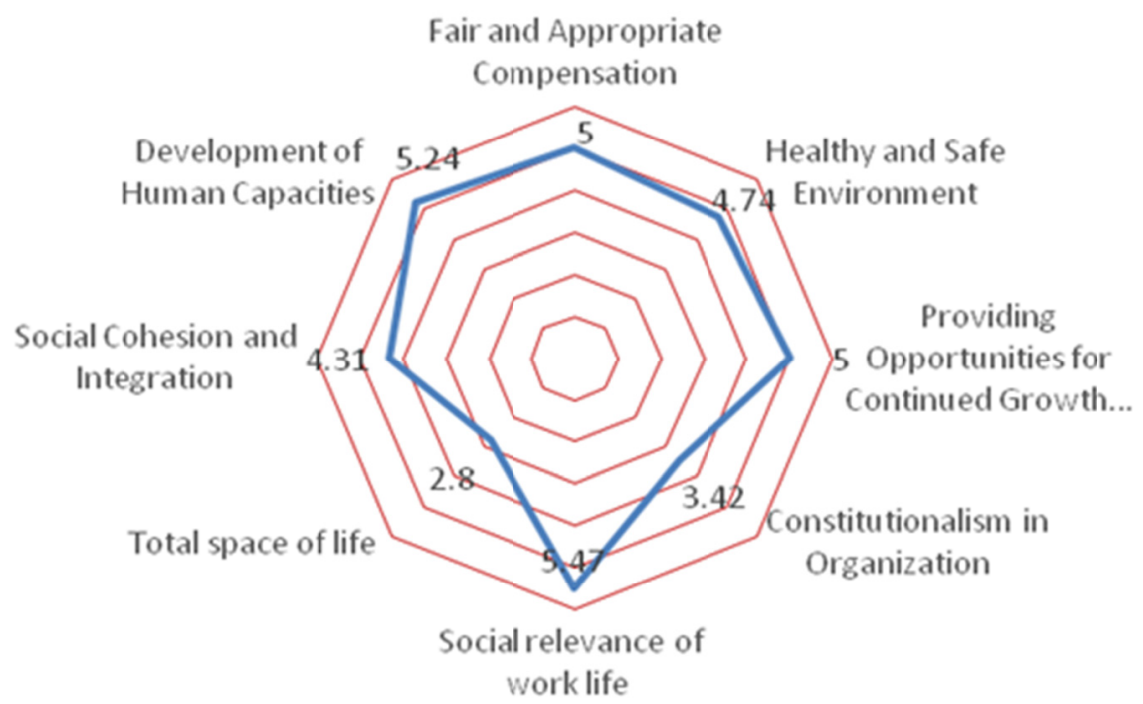

Figure 2. Spider diagram for components

Table 9 shows reliability and validity of the different items as calculated by PLS-SEM. As can be see, for all components, Cronbach's alpha values and Composite reliability (CR) are higher than 0.7 and shared values are higher than 0.5; therefore the measurement model is reliable (Hair et al.,2006). The Loading (factor) for all the indices is greater than 0.7 , and since the t-value coefficients for all indices are outside [-2/58, 2/58], so it is highly possible that all the loading factors are significant. The average variance extracted (AVE) values for all the components are higher than 0.5, and all the CR values of the indices are higher than their corresponding AVE values (Hair et al.,2006). So the convergent validity of the model is guaranteed. In order to examine the validity of the model, the AVE and the correlation coefficient between latent variables were used using Fornell and Larcker's method (1981). As shown in Table 10, since the square root of the AVE of each component is greater than its correlation with other components, so the divergent validity of the model is established. 
Table 9. The summarized results of the measured model

\begin{tabular}{|c|c|c|c|c|c|c|c|}
\hline Latent variable & Indicators & Loading & $\mathrm{t}$-value & $\begin{array}{l}\text { Cronbach's } \\
\text { alpha }\end{array}$ & $\begin{array}{l}\text { Composite } \\
\text { reliability }\end{array}$ & Communality & AVE \\
\hline \multirow{3}{*}{ Fair payment } & AQ1 & 0.871600 & 17.867390 & \multirow[t]{3}{*}{0.834373} & \multirow[t]{3}{*}{0.898961} & \multirow[t]{3}{*}{0.747960} & \multirow[t]{3}{*}{0.747960} \\
\hline & $\mathrm{AQ} 2$ & 0.834926 & 11.437490 & & & & \\
\hline & AQ3 & 0.887181 & 33.655747 & & & & \\
\hline \multirow{3}{*}{$\begin{array}{l}\text { Safe working } \\
\text { environment }\end{array}$} & BQ1 & 0.840462 & 31.538705 & \multirow[t]{3}{*}{0.728575} & \multirow[t]{3}{*}{0.845793} & \multirow[t]{3}{*}{0.646719} & \multirow[t]{3}{*}{0.646719} \\
\hline & BQ2 & 0.770175 & 19.865709 & & & & \\
\hline & BQ3 & 0.800381 & 30.007899 & & & & \\
\hline \multirow{4}{*}{$\begin{array}{l}\text { Growth supply } \\
\text { opportunities }\end{array}$} & CQ1 & 0.890306 & 60.289899 & \multirow[t]{4}{*}{0.856695} & \multirow[t]{4}{*}{0.902877} & \multirow[t]{4}{*}{0.699654} & \multirow[t]{4}{*}{0.699654} \\
\hline & $\mathrm{CQ} 2$ & 0.857379 & 47.051076 & & & & \\
\hline & CQ3 & 0.790031 & 32.919322 & & & & \\
\hline & CQ4 & 0.804191 & 29.172933 & & & & \\
\hline \multirow{4}{*}{$\begin{array}{l}\text { Rule obedience in } \\
\text { organization }\end{array}$} & DQ1 & 0.811393 & 32.168300 & \multirow[t]{4}{*}{0.836758} & \multirow[t]{4}{*}{0.891013} & \multirow[t]{4}{*}{0.671592} & \multirow[t]{4}{*}{0.671592} \\
\hline & DQ2 & 0.844392 & 45.036472 & & & & \\
\hline & DQ3 & 0.792343 & 30.590515 & & & & \\
\hline & DQ4 & 0.828979 & 36.040414 & & & & \\
\hline \multirow[t]{2}{*}{ Social dependency } & EQ1 & 0.907205 & 65.955744 & \multirow[t]{2}{*}{0.787496} & \multirow[t]{2}{*}{0.903951} & \multirow[t]{2}{*}{0.824736} & \multirow[t]{2}{*}{0.824736} \\
\hline & EQ2 & 0.909094 & 80.309424 & & & & \\
\hline \multirow{4}{*}{ General life space } & FQ1 & 0.712873 & 8.169146 & \multirow[t]{4}{*}{0.809103} & \multirow[t]{4}{*}{0.856180} & \multirow[t]{4}{*}{0.600365} & \multirow[t]{4}{*}{0.600366} \\
\hline & FQ2 & 0.885923 & 24.558896 & & & & \\
\hline & FQ3 & 0.697015 & 7.364222 & & & & \\
\hline & FQ4 & 0.789041 & 10.516606 & & & & \\
\hline & GQ1 & 0.730428 & 21.100958 & 0.823375 & 0.882520 & 0.653295 & 0.653295 \\
\hline Social solidarity & GQ2 & 0.811549 & 32.100606 & & & & \\
\hline & GQ3 & 0.853848 & 48.017424 & & & & \\
\hline & GQ4 & 0.831857 & 31.201004 & & & & \\
\hline The development of & HQ1 & 0.868864 & 55.565539 & 0.864290 & 0.901667 & 0.647608 & 0.647608 \\
\hline human capabilities & HQ2 & 0.805531 & 30.479145 & & & & \\
\hline & HQ3 & 0.756701 & 22.172082 & & & & \\
\hline & HQ4 & 0.802653 & 30.554287 & & & & \\
\hline & HQ5 & 0.785741 & 26.807735 & & & & \\
\hline
\end{tabular}

Table 10. Fornell-Larcker standard analysis to check the divergent validity

\begin{tabular}{|c|c|c|c|c|c|c|c|c|}
\hline & $\# 1$ & $\# 2$ & $\# 3$ & $\# 4$ & $\# 5$ & $\# 6$ & $\# 7$ & $\# 8$ \\
\hline $\begin{array}{l}\text { \#1 Fair } \\
\text { payment }\end{array}$ & $\begin{array}{l}0.8648 \\
46807 \\
\end{array}$ & & & & & & & \\
\hline $\begin{array}{c}\text { \#2 Safe } \\
\text { working } \\
\text { environment }\end{array}$ & $\begin{array}{c}0.4303 \\
60\end{array}$ & $\begin{array}{c}0.8041884 \\
11 \\
\end{array}$ & & & & & & \\
\hline $\begin{array}{l}\text { \#3 Growth } \\
\text { supply } \\
\text { opportunities }\end{array}$ & $\begin{array}{c}0.4294 \\
28\end{array}$ & 0.360855 & $\begin{array}{c}0.8364532 \\
26\end{array}$ & & & & & \\
\hline $\begin{array}{c}\text { \#4 Rule } \\
\text { obedience in } \\
\text { organization }\end{array}$ & $\begin{array}{c}0.0387 \\
39\end{array}$ & 0.251641 & 0.507559 & $\begin{array}{c}0.8195071 \\
69\end{array}$ & & & & \\
\hline $\begin{array}{c}\text { \#5 Social } \\
\text { dependency }\end{array}$ & $\begin{array}{c}-0.007 \\
231\end{array}$ & 0.149155 & 0.352216 & 0.589154 & $\begin{array}{c}0.9081497 \\
67\end{array}$ & & & \\
\hline $\begin{array}{l}\text { \#6 General } \\
\text { life space }\end{array}$ & $\begin{array}{c}0.1270 \\
19 \\
\end{array}$ & 0.342275 & 0.291477 & 0.269332 & 0.118330 & $\begin{array}{c}0.7748328 \\
85 \\
\end{array}$ & & \\
\hline $\begin{array}{l}\text { \#7 Social } \\
\text { solidarity }\end{array}$ & $\begin{array}{c}0.0762 \\
34 \\
\end{array}$ & 0.218516 & 0.468989 & 0.658586 & 0.507207 & 0.170399 & $\begin{array}{c}0.8082666 \\
64 \\
\end{array}$ & \\
\hline $\begin{array}{c}\text { \#8 The } \\
\text { development } \\
\text { of human } \\
\text { capabilities }\end{array}$ & $\begin{array}{c}0.2385 \\
76\end{array}$ & 0.218124 & 0.535481 & 0.511784 & 0.562202 & 0.256452 & 0.532080 & $\begin{array}{c}0.8047409 \\
52\end{array}$ \\
\hline
\end{tabular}

In table 11, the criteria for the evaluation of the structural model have been reported. As it can be seen, the t-value for all the components is outside [-2/58, 2/58], therefore all the components can explain the employees' quality of working life. R2 and CV Redundancy values for the variables of Growth supply opportunities, Rule obedience in organization, Social dependency, Social solidarity, and the development of human capabilities were high, for the variable of Safe working environment they were average, and these values were low to average for the variables of General life space and Fair payment. In addition, GoF (The goodness-of-fit) criterion was used to determine the overall quality of the model, which 
was 0.54 . This value is much more higher than the threshold value of 0.35 (Wetzels, Odekeken-schoroder, \& Van Oppen, 2009). This shows that the overall quality of our model is very high.

Table 11. The results of the structural model

\begin{tabular}{c|c|c|c}
\hline & t-value & $\mathbf{R}^{2}$ & CV Redundancy \\
\hline \#1 Fair payment & 3.600310 & 0.120747 & 0.083527 \\
\hline \#2 Safe working environment & 6.298034 & 0.213384 & 0.135152 \\
\hline \#3 Growth supply opportunities & 23.175433 & 0.610071 & 0.423752 \\
\hline \#4 Rule obedience in organization & 22.449201 & 0.637535 & 0.427208 \\
\hline \#5 Social dependency & 11.950242 & 0.440341 & 0.363860 \\
\hline \#6 General life space & 6.764435 & 0.172074 & 0.072776 \\
\hline \#7 Social solidarity & 21.756772 & 0.588544 & 0.375149 \\
\hline \#8 The development of human capabilities & 34.344075 & 0.651023 & 0.411808 \\
\hline \multicolumn{3}{|l|}{}
\end{tabular}

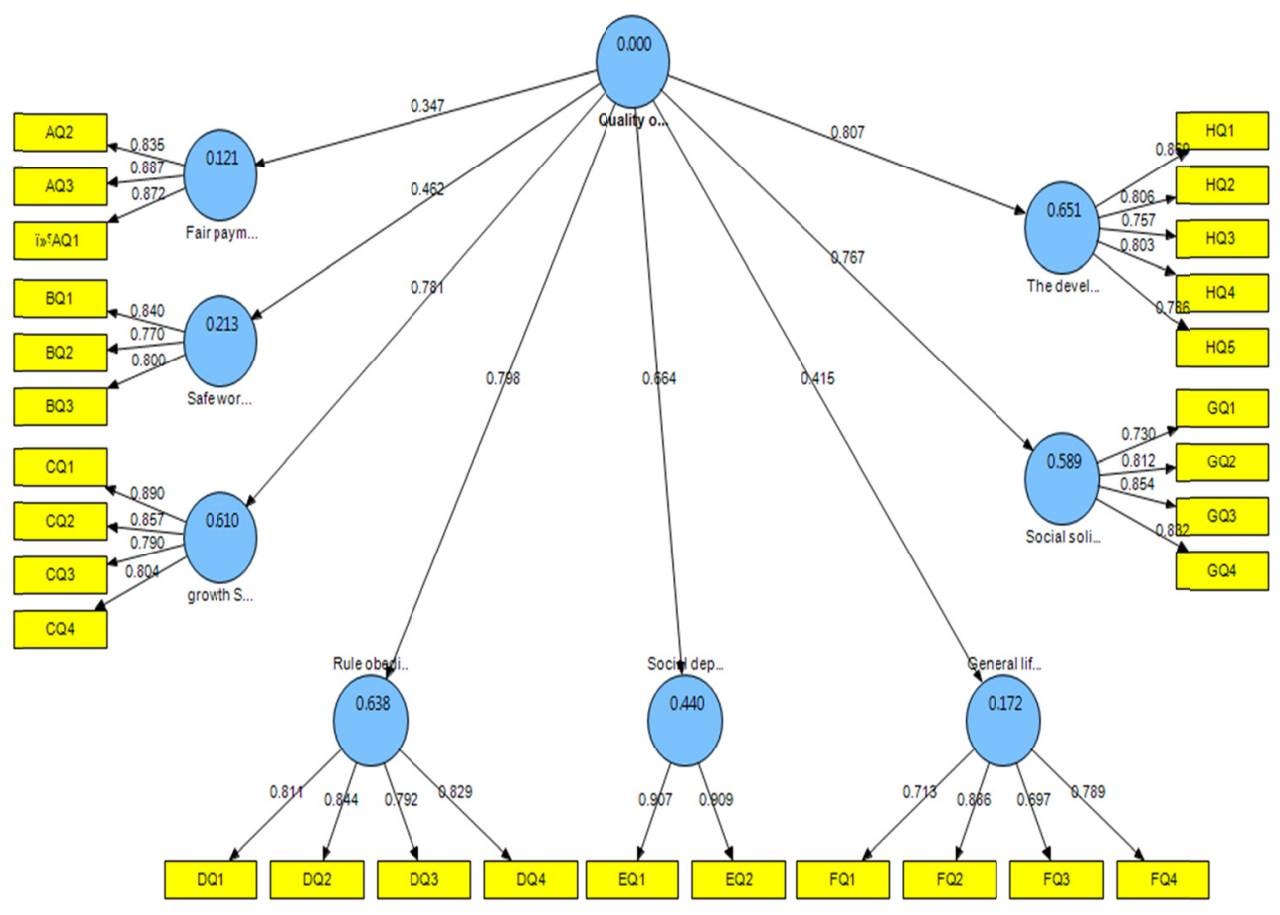

Figure 3. Direction model and the results of PLS-SEM

The main objective of this study was to investigate factors affecting employees' QWL and assess the status of these factors in the company under study. In this regard, first, a main hypothesis and eight sub-hypotheses were proposed to achieve the intended goals.

The results of "one-series Wilcoxon test" suggest that:

- The test is significant in 'fair and adequate compensation', ' providing opportunities for continued growth and safety', 'social relevance of work life', and 'development of human capacities'.

- 'Healthy and safe environment' and 'social cohesion and integrity' are average.

- 'Constitutionalism in organization' and 'total space of life' are low, and more attention is needed to be paid to the needs and expectation in these components.

Overall, the total score obtained is average, and the hypothesis for its greater value is not approved. In other words, the status of employees' QWL is average in the company under study.

The results of "Friedman test" reveal that:

The status of employees' QWL components is not equal. In other words, there is priority in assessing the status of components. Given the prioritization, the status of 'social relevance of work life' is of utmost importance; and in the same vein, 'constitutionalism in organization' and 'total space of life' are of the least importance.

In general, the sub-hypotheses related to 'adequate and safe compensation', 'providing opportunities for continued 
growth and safety', 'social relevance of work life', and 'development of human capacities' are confirmed as the probability value is less than 0.05 .

\section{Discussion}

The importance of the present study done in the studied organization is based on the assumption that the quality of working life and the measurement of its components can help the management of human resources of the organization to identify the obstacles and problems which employees are facing, and then to implement the appropriate policies to increase the employees' job satisfaction and to improve their level of involvement, a high level of mutual commitment between employees and the organization, and finally the organization's effectiveness. Therefore, there seemed to be a research gap in the employees' quality of working life in the studied organization.

The findings of first sub-hypotheses: The first research sub-hypothesis is that fair and adequate compensation is at an appropriate level in the intended company. The results revealed that fair and adequate compensation is at an appropriate level at 5\% significant level with 0.001 probability value and 3.165 median value. Therefore, the above hypothesis is confirmed. Studies have been emphasized by Huang, Lawler, and Lee (2007), Sinha (2012), Gayathiri, and Lalitha (2013).

The company which was studied in the present survey is a public company, and according to Daley (2005) the structure of payments (bonuses, salaries and wages) in public organizations imposes serious limitations on the purposes of judgment regarding the evaluation of performance in areas such as promotion and merit pay, and especially merit pay is used as a tool both to increase productivity and to reduce costs in many public organizations. Although this factor is in a good condition in the present company, the results of some research (Shahbazi et al, 2010) show that improving the quality of working life in Iran depends on improving the economic situation, and choosing long-term strategies by the government, and their implementation and evaluation they can have a significant impact on quality of life and work in the future. Hence, the company managers are recommended to pay more attention to compensation and reward systems in order to improve the employees' quality of working life, and be able to improve the company's working life using effective policies such as adaptation of the salaries and benefits of the employees to their expectations, timely payment of wages and benefits, on time payment, rewards to motivate employees to improve innovation and creativity in providing services, and so on.

The findings of second sub-hypotheses: The second research sub-hypothesis is that healthy and safe environment is at an appropriate level in the intended company. The results displayed that healthy and safe environment is at an average level at $5 \%$ significant level with 0.178 probability value and 3.000 median value. Hence, the above hypothesis is rejected. Based on this studies have been reported by Niosh (2010), Adhikari \& Gautam (2010), Gayathiri \& Lalitha (2013).

The results of Seidler et al. (2014) and Pollock's (1993) studies suggest that the psychological needs of employees in organizations are fulfilled through the application of working life quality techniques. Thus, regarding the fact that human resources are the most important and most essential element of any organization, and success of any organization in achieving its goals heavily depends on human resources, attending to employees' physical and psychological needs is essential, and constant effort should be made to meet these needs. The results of Arsalani et al's (2014) study indicate that one fourth of Iranian nurses suffer from physical damages due to work, and one out of three people gets backache related to their job. In addition, Bernal et al. (2015) maintain that every week, $7.4 \%$ of the nurses will be absent from work because of work-related mental or physical fatigue, which is $80 \%$ higher than that of other professional groups. These factors are closely connected to the quality of their working life, and can also cause disruption to their personal lives. If continued, these disruptions lead to many social, personal, economical, and psychological problems, and can cause sexual disorders and impair their performance.

The findings of third sub-hypotheses: The third research sub-hypothesis is that providing opportunities for continued growth and safety is at an appropriate level in the intended company. The results suggested that providing opportunities for continued growth and safety is at an appropriate level at $5 \%$ significant level with 0.005 probability value and 3.125 median value. Hence, the above hypothesis is confirmed.

Filipo (1998) believed that quality of working life programs include any improvement in the organizational management which brings about success and development. Almalki et al (2012) and Dolan et al (2008) maintained that development opportunities and job promotions have a positive effect on the quality of working life. Deutsch and Schurman (1993) suggested that quality of working life programs applied in the United States of America increase employees' participation in making decisions about new technologies, workplace environment, and skills training. Chaipol (1990) examined middle managers perception of their quality of work life in three American, Japanese, and Thai companies, and found out that compared to Japanese companies, American companies had a higher quality of work life in payment, opportunity promotion, and training opportunities, while the Thai company had a higher quality 
than the Japanese ones with regard to opportunity training. Although the studied company is in a good condition with regard to this factor, the company's mangers are recommended to attempt to make the workplace ergonomic in order to improve their employees' physical health, and encourage them to exercise to improve their psychological condition

The findings of fourth sub-hypotheses: The fourth research sub-hypothesis is that constitutionalism in organization is at an appropriate level in the intended company. The results indicated that constitutionalism in organization is not at an appropriate level at $5 \%$ significant level with 1.000 probability value and 2.275 median value. Therefore, the above hypothesis is rejected.

The component of rule observation refers to fair, indiscriminate, and respectful behavior towards employees, and is expected to be a significant factor in employees' tendency to change their jobs. Stapenhurst and Langseth (1997) believed that authority of law can improve the quality of life. The results of the studies done by Almalki et al. (2012) and Dolan et al. (2008) revealed that rule observation has a positive effect on quality of working life. Rosenbloom and Rene (2010) claimed that rules and principles regulate people's behavior and their interaction with each other; ensure accountability, equality, and ethical behavior; and form the foundation of any organization. Chimwaza et al. (2014) maintained that lack of support by managers and their unfair behavior towards employees were a significant factor in health service staff members' tendency to leave their jobs. The findings of Gordon's study (1993) showed that paying attention to rule observation and quality of working life programs reduces staff members' complaints, absenteeism, and disciplinary actions, and at the same time increases participation and staff members' positive attitudes. Regarding the fact that the component of rule observation in the studied company is in a poor condition, the company's managers, and especially its board of directors should adopt effective policies to improve rule observation. So, it is recommended that the managers of the company attempt to improve the organizational justice in distributive dimension (allocation of reward based on employee's performance), procedural dimension (managers' attention to observing the fair procedure of employees' annual evaluation system solely based on performance), and interactive dimension (appropriate behavior towards employees). In addition, Cole and Parston (2006) are of the opinion that when there is a democratic atmosphere in a company, staff members are able to freely express their ideas, attitudes, and expectations, which helps company's managers adopt effective policies, make key decisions and find out the facts. So, the company's managers should attempt to create a supportive organizational culture and a democratic atmosphere in order to improve the quality of work life.

The findings of fifth sub-hypotheses: The fifth research sub-hypothesis is that social relevance of work life is at an appropriate level in the intended company. The results revealed that social relevance of work life is at an appropriate level at $5 \%$ significant level with 0.000 probability value and 3.250 median value. Therefore, the above hypothesis is confirmed. Based on this studies have been reported by Boutin-Dufresne, and Savaria(2004), Porter \& Kramer(2002).

The results of Rubel and Kee's study (2014) indicated that the quality of work life affects the employees' performance and organizational efficiency by influencing their job satisfaction. Therefore, workplace is of high quality, when its staff members are assumed as the main component of the organization; they encounter intellectual challenges; the workplace brings about its members' success and personal capability; and everything is done perfectly.

Since the studied company is a project-oriented company in the field of gas delivery to citizens, the senior managers of the company are recommended to protect the environment as a national asset while running gas-delivery projects, and the studied company should be more responsible towards society affairs. Respecting the Constitution of the country and other authorities, this company is expected to improve its quality of work life. As the results of the studies done by Almalki et al. (2012), Stapenhurst and Langseth (1997), and Dolan et al. (2008) showed, law making and the authority of law can positively affect the quality of work life.

The findings of sixth sub-hypotheses: The sixth research sub-hypothesis is that total space of work life is at an appropriate level in the intended company. The results indicated that total space of work life is not at an appropriate level at $5 \%$ significant level with 1.000 probability value and 2.500 median value. Therefore, the above hypothesis is rejected.

Findings of Narehan et al.'s study (2014) on multi-national companies in Malaysia indicated that quality of work life (QWL) has a significant effect on employees' quality of life (QOL). Beasley et al. (2005) believed that most of the factors affecting the quality of work life depend on employees' ability to keep a balance between home and work. The results of the study by Zhao et al. (2013) showed that the quality of work life affects other aspects of life such as family life, social life, and other psychological aspects of life which are not related to the job.

The findings of seventh sub-hypotheses: The seventh research sub-hypothesis is that social cohesion and integration is at an appropriate level in the intended company. The results revealed that social cohesion and integration is at an average level at $5 \%$ significant level with 0.878 probability value and 3.000 median value. Therefore, the above hypothesis is rejected. Based on this studies have been reported by Lee et al (2015). 
The findings of Marginean et al's (2006) study revealed that quality of work life is a process by which the staff members of an organization can influence major decisions through appropriate communication channels (organizational hierarchies) designed for such purposes, and this plays a key role in social integration of the workplace. Zhao et al. (2013) claimed that quality of work life has a positive effect on the improvement of job attitudes such as organizational commitment, job dependence, job attachment, and joy in the workplace. Based on the findings of Zhao et al.'s study, it can be concluded that the improvement of job attitudes leads to social integrity and solidarity in the organization.

Therefore, the findings of the studies done by Marginean et al. (2006) and Zhao et al. (2013) can be used to help senior managers of Gas Company to adopt effective policies in order to maintain social integrity and improve the quality of working life.

The findings of eighth sub-hypotheses: The eighth research sub-hypothesis is that development of human capacities is at an appropriate level in the intended company. The results indicated that development of human capacities is at an appropriate level at $5 \%$ significant level with 0.000 probability value and 3.200 median value. Therefore, the above hypothesis is confirmed.

\section{Suggestions for Further Research}

Regarding the topic of the paper, other research projects related to the employees' quality of life in the studied organization have been proposed as follows:

1. The relationship between the quality of working life and work-life balance, organizational citizenship behavior, organizational commitment, conflict, job satisfaction.

2. The impact of the employees' quality of working life on the quality of the customer service.

3. Designing an effective model for measuring the employees' quality of working life.

\section{Limitations}

One of the limitations of this study was the presence of uncontrollable factors, such as different life schedules, individual habits and work schedules, which could affect the resting time of nurses before working shifts or during the day after shifts, ultimately diminishing their quality of sleep and general health.

\section{References}

Adhikari, D. R., \& Gautam, D. K. (2010). Labor Legislations for Improving Quality of work life in Nepal. International Journal of Law and Management, 52(1), 40-53. https://doi.org/10.1108/17542431011018534

Akder, M. (2006). Improving Quality of work life implications for Human resource, The Business Review, Cambridge, 6(1), 173-177.

Alfonso, L., Zenasni, F., Hodzic, S., \& Ripoll, P. (2016). Understanding The Mediating of Quality of Work Life on the Relationship between Emotional Intelligence and Organizational Citizenship Behaviors, Psychological Reports, 118(1), 107-127. https://doi.org/10.1177/0033294115625262

Almalki, M. J., Fitzgerald, G., \& Clark, M. (2012). Quality of work life among primary health care nurses in the Jazan region, Saudi Arabia: a cross-sectional study. Human Resource Health, 10(1), 30. https://doi.org/10.1186/1478-4491-10-30

Almarsh, O. S. (2015). A measurement Scale for Evaluating Quality of Work Life: Conceptualization and Empirical Validation, Trends in Applied Research, 10(3), 143-156. https://doi.org/10.3923/tasr.2015.143.156

Arsalani, N., Fallahi, K. M., Josephson, M., \& Lagerstrom, M. (2014). Musculoskeletal disorders and working conditions among Iranian nursing personnel, International Journal of Occupation safety and Ergonomics, 20(4). 671-680. https://doi.org/10.1080/10803548.2014.11077073

Bagtasos, M. R. (2011). Quality of Work Life: A Review of Literature. DLSU Business and Economics Review, 20(2). https://doi.org/10.3860/ber.v20i2.1909

Beasley, J. W., Karsh, B. T., Sainfort, F., Hagenauer, M., Mary, E., \& Marchand, L. (2005). Quality of work life of family physicians in Wisconsin health care organization. Official Publication of the State Medical Society Wisconsin, 103(7), 51-55.

Belcher, J. (1987). Productivity Plus. Houston Texas: Gulf Publishing Company, Hoston Texsas, 1-10.

Bernal, D., Campos, S. J., Tobias, A., Vargas, P. S., Benavides, F. G., \& Serra, C. (2015). Work-related psychosocial risk factors and musculoskeletal disorders in hospital nurses and nursing aides: A systematic review and meta-analysis, International Journal of Nursing Studies, 52(2), 635-648. https://doi.org/10.1016/j.ijnurstu.2014.11.003 
Boutin, D. F., \& Savaria, P. (2004). Corporate Social Responsibility and Financial Risk. The Journal of Investing, 13(1), 57-66. https://doi.org/10.3905/joi.2004.391042

Chaeung, F. Y. L., \& Tang, C. S. K. (2009). Quality of Work Life as a Mediator Between Emotional Labor and Work Family Interference. Journal of Business and Psychology, 24(3), 245-255. https://doi.org/10.1007/s10869-009-9103-7

Chaipol, H. (1990). A comparative study of Thai middle managers perception of their quality of work life in American-Owned, Japanese and that owned companies operating in Thailand. (Unpublished Doctoral Dissertation). United State International University.

CheRose, R., Beh, L. S., Uli, J., \& Idris, K. (2006). An Analysis of Quality of Work Life (QWL) and Career- Related Variables. American Journal of Applied Sciences, 3(12), 2151-2159. https://doi.org/10.3844/ajassp.2006.2151.2159

Chimwaza, W., Chipeta, E., Ngwira, A., Kamwendo, F., Taulo, F., \& Bradly, S. (2014). What makes Staff Consider Leaving the Health Service in Malawi? Human resource for Health, 12(1), 12-17. https://doi.org/10.1186/1478-4491-12-17

Cole, M., \& Parston, G. (2006). Unlocking Public Value: A New Model for Achieving High Performance in Public Service Organizations. John Wiley \& Sons.

Deutsch, S., \& Schurman. (1993). Labor Initiatives for worker participation and quality of worklife. Economic and Industrial Democracy, 14, 345-354. https://doi.org/10.1177/0143831X93143004

Dolan, S. L., Garcia, S., Cabezas, C., \& Tzafrir, S. S. (2008). Predictors of quality of work and poor health among primary health-care personnel in Catalonia: Evidence based on cross-sectional, retrospective, and longitudinal design, International Journal of Health care Quality Assurance, 21(2), 203-218. https://doi.org/10.1108/09526860810859058

Erdem, M. (2014). The Level of Quality of Work Life to predict work Alienation, Educational Sciences: Theory \& Practice, 14(2).

Filipo, B. (1988). Personnel management (6th edition), Mc-Grow-Hill, international edition.

Fornell, C., \& Larcker, D. F. (1981). Evaluating structural equation models with unobservable variables and measurement error. Journal of Marketing Research, 18(1), 39-50. https://doi.org/10.2307/3151312

Gayathiri, R., \& Lalitha, R. (2013). Quality of work life-linkage with job satisfaction and performance, International Journal Business and Management Invention, 2(1), 1-8.

Giang, T. P., \& Trung, Q. V. (2016). A Literature Review on Quality of Working Life: A Case of Healthcare Workers, Journal of Applied Pharmaceutical Science, 6(07), 193-200. https://doi.org/10.7324/JAPS.2016.60729

Gordon, J. R. (1993). Personnel Management, 6th Ed, New York: MC Graw-Hill.

Hair, J. F., Black, W. C., Babin, B. J., Anderson, R. F., \& Tatham, R. L. (2006). Multivariate data analysis (6 ${ }^{\text {th }}$ Edition), Upper Saddle River, NJ: Pearson prentice Hall.

Huang, T. C., Lawler, J., \& Lee, C. Y. (2007). The effects of quality of work life on commitment and turnover intention. Social Behaviour and Personality an International Journal, 35(6), 735-750. https://doi.org/10.2224/sbp.2007.35.6.735

JiaHaiwei, G. F. (2005). Deliberation and Analysis of the quality of work life of Faculties of Universities and Colleges, Journal of Hebei University of Science and Technology, 5(4).

Kanten, S., \& Sadullah, O. (2012). An empirical research on relationship quality of work life and work engagement. Procedia-Social and Behavioral Sciences, 62(24). https://doi.org/10.1016/j.sbspro.2012.09.057

Kaplan, R. S., \& Norton, D. P. (1996). The balanced scorecard: translating strategy into action. Harvard Business Press.

Koonme, K., \& Singhapakdi, A. (2009). Ethics institualization, quality of work life, and employee job-related outcomes: a survey of human resource managers in Thailand, Journal of business research. 63(1), 20-26.

Lau, R. S. M., \& Bruce, E. M. (1998). A win-win paradigm for quality of work life and business performance. Human Resource Development Quarterly, 9(3), 211-26. https://doi.org/10.1016/j.sbspro.2012.09.057

Lee, D. J., \& Singhapakdi, A. (2007). Further Validation of a Need-based Quality-of-work-life (QWL) Measure: Evidence from Marketing Practitioners, Applied Research in Quality Life. 273-287. 
https://doi.org/10.1007/s11482-008-9042-x

Lee, Y. W., Dai, Y. T., \& McCreary, L. L. (2015). Quality of work life as a predictor of nurses' intention to leave units, organisations and the profession. Journal of Nursing Management, 23(4), 521-531. https://doi.org/10.1111/jonm.12166

Levine, M., Taylor, J., \& Davis, L. (1984). Defining quality of work life. Human Relations, 37(1), 81-104. https://doi.org/10.1177/001872678403700105

Marginean, I., Precupetue, I., Tzanov, V., Preoteasa, A. M., \& Voicu, B. (2006). First European quality of life survey: Quality of life in Bulgaria and Romania, European foundation for the improvement of living and working conditions, 1-75.

Martel, J. P., \& Dupuis, G. (2006). Quality of Work Life: Theoretical and Methodological Problems, and Presentation of a new Model and Measuring Instrument, Social Indicators Research, 77(2), 333-368. https://doi.org/10.1007/s11205-004-5368-4

Maxwell, G. A. (2005). Checks and balance: The role of managers in work-life balance policies and practices. Journal of Retailing and consumer services, 12(3), 179-189. https://doi.org/10.1016/j.jretconser.2004.06.002

Mitchell, J. I. (2012). Work life and patient Safety Culture in Canadian Healthcare: Connecting the Quality Dots using National Accreditation Results. Healthcare Quarterly, 15(1), 51-58. https://doi.org/10.12927/hcq.2012.22765

Mohammadi, N. S., \& Abdullah, M. A. (2011). Quality of work life among factory workers in Malaysia. Procedia-Social and Behavioral Sciences, 35, 739-745. https://doi.org/10.1016/j.sbspro.2012.02.144

Nadler, A. D., \& Lawler, E. E. (1983). Quality of work life: perspective and directions, Organizational Dynamics, 11(3), 20-30. https://doi.org/10.1016/0090-2616(83)90003-7

Narehan, H., Hairunnisa, M., Norfadzillah, P., \& Freziamella, L. (2014). The Effect of Quality of Work life Programs on Quality of life among Employees at Multinational companies in Malaysia. Procedia- Social and Behavioral Sciences, 112(7), 24-34. https://doi.org/10.1016/j.sbspro.2014.01.1136

Niosh. (2010). Quality of work life questionnaire- Overview, Retrieved from http://www.cdc.gov/niosh/topics/stress/qwlquest.html

Nitesh, S., \& Devendra, S. V. (2013). Importance of Quality of Work Life in Small Scale industries for employees. International Journal of Latest Research in Science and Technology, 2(2), 153-156.

Parsa, B., Idris, K., Samah, B., Wahat, N., \& Parsa, P. (2014). Relationship between Quality of Work Life and Career advancement among Iranian academics, Procedia-Social and Behavioral Science, 152(7), 108-111.

Pollock, S. (1993). Doing Organizational Effectiveness Effectively. Journal of Quality \& Participation, 16(5).

Porter, M. E., \& Kramer, M. R. (2002). The Competitive Advantage of corporate Philanthropy. Harvard Business Review, 80(12), 56-68.

Quick, J. D., Wright, T. A., \& Adkins, J. A. (2013). Preventive stress management in organizations, ( ${ }^{\text {nd }}$ ed). Washington, DC: American Psychological Association. https://doi.org/10.1037/13942-000

Reddy, D. M. L., \& Reddy, P. D. M. (2014). Comparative analysis of Quality of Work Life among Public and Private Sector bank employees, International Journal of Organizational Behavior \& Management perspectives, 2(4), 641-648.

Rethinam, G. S., \& Maimuhan, I. (2008). Constructs of Quality of Work Life: A Perspective of Information and Technology Professionals. European Journal of Social Sciences, 7(1), 58-70.

Robbins, S. P. (1989). Organizational Behavior: Concepts, Controversies, and Applications, New Jersey: Prentice Hall.

Roos, G., \& Roose, J. (1997). Measuring Your Company Intellectual performance, Long Range planning, 30(3), 413-426.

Rosenbloom, D., \& Rene, H. (2010). Foundations of Public Administration: Administrative Law, Public Administration Review (PAR), 1-5.

Rubel, M. R. B., \& Kee, D. M. H. (2014). Quality of Work Life and Employee performance: Antecedent and Outcome of Job Satisfaction in Partial Least Square. World Applied Sciences Journal, 31(4), 456-467. https://doi.org/10.5829/idosi.wasj.2014.31.04.142

Seidler, A., Thinschmidt, M., Deckert, S., Then, F., Hegewald, J., Nieuwenhuijsen, K., \& Riedel, H. S. G. (2014). The Role of psychosocial working conditions on burnout and its core component emotional exhaustion- a systematic 
review, Journal of Occupational Medicine and Toxicology, 9(10). https://doi.org/10.1186/1745-6673-9-10

Sinha, C. (2012). Factors affecting Quality of work life: Empirical evidence from Indian organizations, Australian Journal of Business and Management Research, 1(11), 31-40

Stapenhurst, F., \& Langseth, P. (1997). The Role of the Public Administration in Fighting Corruption, International Journal of Public Sector Management, 10(5), 311-330.

Stein, B. (1983). Quality of Work Life in Action: Managing for Effectiveness, New York, AMA Membership Publications Division, American Management Associations.

Stephen, A. (2012). Quality of Work Life in Small Scale Industrial Units. Employers and Employees Perspectives. Research Journal of Social Science \& Management, 28(2), 262-271.

Stone, R. J. (1998). Human Resource Management, Australia: John Wiley and Sons Ltd.

Susan, V., \& Jayan, C. (2013). Quality of Work Life: A Dynamic Multidimensional Construct at Work Place - Part II. Guru Journal of Behavioral and Social Sciences, 1(2), 91-104.

Tabassum, A., \& Rahman, T., \& Jahan, K. (2011). A comparative analysis of quality of work life among the employees of local private and foreign commercial banks in Bangladesh, World Journal of social science, 1(1).

Teryima, S. J., \& Faajir, A., \& John, E. (2016). Examining employee quality of work life as a determinant of managerial effectiveness in business organizations, The Business and Management Review, 7(3), 268-281

Troshani, I., \& Jerram, C., \& Rao, H. S. (2011). Exploring the public sector adaption of HRIS, Industrial Management \& Data System, 111(3), 470-488.

Tuttle, T. C. (1983). Organizational Productivity A Challenge for Pscholigists. American Pscholigist, 38(4) $479-486$. https://doi.org/10.1037/0003-066X.38.4.479

Walton, R. (1975). Criteria for quality of work life, in L.E. Davis and R.L. Cherns, The Quality of Working Life: Problems, Prospects, and the State of the Art, Vol.1, Free Press, New York.

Wetzels, M., Odekerken, S. G., \& Vanoppen, C. (2009). Using PLS Path Modeling for Assessing Hierarchical Construct Models: Guidelines and empirical illustration, MIS quarterly, 33(1), 177-195.

Wyatt, T. A., \& Wah, C. Y. (2001). Perception of Quality of Work Life: A Study of Singaporean Employees Development, Research and Practice in Human Resource Management, 9(2), 59-76.

Zhao, X., Sun, T., Cao, Q., Li, C., Duan, X., Fan, L., \& Liu, Y. (2013). The impact of quality of work life on job embeddedness and affective commitment and their co-effect on turnover intention of nurses. Journal of Clinical Nursing, 22(5/6), 780-788.

\section{Copyrights}

Copyright for this article is retained by the author(s), with first publication rights granted to the journal.

This is an open-access article distributed under the terms and conditions of the Creative Commons Attribution license which permits unrestricted use, distribution, and reproduction in any medium, provided the original work is properly cited. 